\title{
ЕТАПИ ФОРМУВАННЯ ПРОФЕСІЙНО-ПЕДАГОГІЧНОЇ КОМПЕТЕНТНОСТІ МАГІСТРА ТЕХНОЛОГІЧНОЇ ОСВІТИ У ПРОЦЕСІ ФАХОВОЇ ПІДГОТОВКИ
}

Ящук С. М. Етапи формування професійно-педагогічної компетентності магістра технологічної освіти у процесі фахової підготовки.

У статті розкрито зміст етапів формування професійно-педагогічної компетентності викладача загальнотехнічних дисциплін та методики навчання технологій, обгрунтовано процеси ії формування і результати.

Ключові слова: магістр, технологічна освіта, викладач загальнотехнічних дисциплін і методики навчання технологій, професійно-педагогічна компетентність.

Ящук С. Н. Этапы формирования профессионально-педагогической компетентности магистра технологического образования в процессе профессиональной подготовки.

В статье раскрывается содержание этапов формирования профессиональнопедагогической компетентности преподавателя общетехнических дисциплин и методики обучения технологий, обоснованы ее формирования процессы и результаты.

Ключевые слова: магистр, технологическое образование, преподаватель общетехнических дисциплин и методики обучения технологий, профессиональнопедагогическая компетентность.

Yashchuk S. M. The stages of forming technology master's professional and pedagogical competency in the process of professional preparation.

The article deals with the stages of forming technology teacher's professional and pedagogical competency and technique of teaching technologies. The author substantiates the processes of its formation and the results.

Key words: master, technological education, technology and technology technique teacher, professional and pedagogical competency.

Система вищої освіти в Україні на сучасному етапі має виходити iз загальнолюдських цінностей, демократичних норм, що передбачає реалізацію фахової підготовки майбутнього спеціаліста на основі особистісно зорієнтованого підходу. За цих умов сучасна система вищої освіти виражає іiі гуманістичні тенденції i характеризуються переходом від традиційних форм освіти до навчання впродовж життя.

Найбільш ефективною умовою підготовки викладача загальнотехнічних дисциплін та методики навчання технологій, як показує практика, є система навчання, процес якої охоплює особистість педагога протягом усього іiі професійного та соціально-активного життя: від елементарного ознайомлення 3 технікою та технологією до сучасної технологічної культури через набуття психологопедагогічної, загальнотехнічної та спеціальної освіти, що забезпечує розвиток рефлексивних здібностей, творчих можливостей, удосконалення професійнопедагогічної майстерності.

Аналіз літературних джерел дає підстави свідчити, що, незважаючи на певну увагу до проблеми формування компетентностей фахівця та наявність результатів дослідження окремих іiі аспектів, питання формування професійно-педагогічної 
компетентності майбутніх викладачів загальнотехнічних дисциплін та методики навчання технологій $є$ недостатньо вивченими в теорії та практиці професійної освіти, зокрема чітко не визначені етапи формування цієї компетентності. Тому дослідження в цьому напрямі $є$ нагальним та потребує грунтовного вивчення.

Під час наукового пошуку з'ясовано, що у процесі професійної підготовки сучасного магістра технологічної освіти до роботи у вищому навчальному закладі формується його професійно-педагогічна компетентність.

У сучасних педагогічних дослідженнях В. Андрущенка, I. Беха, Р. Гуревича, I. Зязюна, І. Козловської, Н. Ничкало, О. Сухомлинської та ін. розглядаються й аналізуються особливості компетентності майбутнього вчителя як особистісного феномену та його складників. Аналіз наукових праць педагогів свідчить, що поняття «професійна компетентність» визначають як «єдність теоретичної готовності педагогічно мислити та практичної готовності педагогічно діяти». Ю. Койнова під професійною компетентністю розуміє «індивідуально-інтегральну якісну характеристику суб'єкта діяльності, цілісний стан та готовність особистості до іï здійснення».

Mema cmammi: обгрунтувати етапи формування професійно-педагогічної компетентності майбутнього викладача загальнотехнічних дисциплін та методики навчання технологій і визначити можливості їх реалізації у процесі професійної підготовки.

Відмова від стереотипів, здатність до інновацій, інтерес до всього нового, але при цьому критичне осмислення запропонованого, вміння підібрати найбільш ефективну для розв'язання педагогічної задачі технологію - все це $є$ складником, що формує професійно-педагогічну компетентність майбутнього магістра технологічної освіти. Оптимальними умовами для формування компетентності педагога, на нашу думку, є: введення майбутніх магістрів у розвивальні ситуації та активне навчальноінформаційне середовище; розкріпачення магістрів у процесі спілкування в індивідуальній формі та в колективі; психокорекція поведінки; набуття нового педагогічного особистісного досвіду; самоаналіз і самооцінка своєї діяльності, критичне ставлення та корекція тощо.

Аналіз педагогічної практики, розроблення та впровадження у навчальновиховний процес магістратури форм і методів, педагогічних умов, які сприяють ефективному формуванню особистості педагога в галузі техніки та технологій, зумовили необхідність визначення та обгрунтування основних етапів формування професійно-педагогічної компетентності, що $\epsilon$ необхідним компонентом професіоналізму майбутнього викладача, який формується у процесі його професійного навчання.

На нашу думку, процес формування професійно-педагогічної компетентності багато в чому залежить від рівня розвитку, освіченості, цілісності особистості здобувача, налаштованої на розкриття як власних, так і дитячих життєвих функцій.

В узагальненій моделі навчання доцільно виокремити чотири стадії, що характеризують процес професійного навчання, починаючи від стадії первинного ознайомлення з новим матеріалом (професійними знаннями, концепціями, навичками тощо) і закінчуючи стадією сформованої професійно-педагогічної компетентності [1].

Перша стадія - «неусвідомлювана» некомпетентність: поки у людини немає необхідних для успішного здійснення професійної діяльності знань, умінь, навичок, вона не знає про їх відсутність або взагалі про можливість існування. Перша стадія характеризується такою професійною самооцінкою суб'єкта: «Я не знаю, що я не знаю». Тут акцент робиться на нерозумінні людиною того, чого (тобто яких знань, 
умінь, навиків) їй бракує.

Звідси витікає, що в конструктивному своєму розвитку перша стадія вже містить елементи усвідомлення браку знань, умінь, навичок. Коли особистість усвідомлює відсутність знань, умінь, навичок, необхідних для певної професійної діяльності, спостерігається друга стадія.

Друга стадія - усвідомлювана некомпетентність: особистість усвідомлює, що ӥй не вистачає необхідних професійних знань, умінь, навичок. На цій стадії можливі два результати:

а) конструктивний, як форма вияву особистісної і професійної активності;

б) деструктивний, як форма професійної та соціальної пасивності. Конструктивний шлях означає, що усвідомлення людиною своєї професійної некомпетентності сприяє підвищенню мотивації на здобуття професійних знань, умінь, навичок, яких їй не вистачає.

Деструктивний результат може привести до виникнення невпевненості в своїх силах, психологічного дискомфорту, підвищеної тривожності тощо, протидіючих подальшому професійному навчанню. Для другої стадії характерна така професійна рефлексія суб'єкта: «Я знаю, що я не знаю».

Третя стадія - усвідомлювана компетентність: людина знає, що входить в структуру і складає зміст, іiі професійних знань, умінь і навичок, вона здатна їх ефективно застосовувати.

Для третьої стадії характерна професійна самооцінка суб’єкта в такій формі: «Я знаю, що я знаю».

Четверта стадія - «неусвідомлювана» компетентність: професійні навички повністю інтегровані, консолідовані з поведінкою; професіоналізм стає властивістю людини. «Неусвідомлювана» компетентність характеризується майстерністю, виконанням багатьох дій на рівні високоавтоматизованих навиків та інтуїції. Людина часто не може пояснити, чому в певній конкретній ситуації вона виконала саме ці дії, що привели до ефективного результату. Проте саме на даному етапі найбільш велика небезпека професійної деформації.

На певних етапах професіоналізації фіксуються деякі періоди і перехідні точки професійного зростання, розглядаючи підвищення рівня професійної компетентності, можна проспостерігати його динаміку.

Як зазначає І. Белоновська, починаючи освоювати нову навичку (рівень свідомої некомпетентності), людина будує певні очікування; отримуючи нові професійні знання і навички, пов'язуючи отримані знання зі своїм досвідом, вона свідомо формує нові уміння або вдосконалює наявні, формуючи ефективніші стратегії поведінки, які, у свою чергу, порівнює з очікуванням [1].

Якщо очікування виправдовуються, то стимульовані емоційним підйомом нові стратегії активно використовуються у професійному та інших контекстах. За відсутності сприятливого професійного («повчального») середовища або можливостей активного використання отриманих знань і навичок, виникає регресія. Людині здається, що новим способом результат досягається набагато повільніше, або 3 меншою ефективністю.

Бар'єр подолання - це критичний період регресу, що характеризується рівнем свідомої некомпетентності, тому що на цьому етапі у людини часто опускаються руки, а вірогідність здатися велика. У цей період люди часто втрачають упевненість в надійності способів і своїх силах: вони повертаються до старої стратегії, первинної компетенції, що дає хоч якийсь результат, не намагаючись просунутися далі. Хтось починає шукати альтернативи, які, можливо, будуть помилковими, або взагалі 
перестає займатися своїм професійним розвитком.

Коли людина методом проб i помилок досягає первинної стабільності професійних навичок, добиваючись успіху раз у раз, у неї виробляється певна стратегія, що незмінно приводить до професійного результату, i, відповідно, відточується майстерність. Особистість відчуває радість від успіху, тому що іiі очікування збулися. Зрозуміло, нова стратегія часто зумовлює новий рівень несвідомої компетентності. Усвідомлення результатів дає можливість інтегрувати знання і навички, отримані в результаті професійної діяльності. Як наслідок на новому, вищому, системнішому рівні виробляються додаткові ефективні стратегії професійної діяльності, що ваблять швидке професійне зростання фахівця, різко підвищують рівень його майстерності [1].

Отже, розглянутий підхід створює можливість аналізу фіксації конкретного етапу професійної компетенції фахівця, виявлення точок «вказаного маршруту» суб'єкта професійної діяльності (індивідуального або колективного) і прогнозування майбутнього.

Кількість періодів професійного розвитку людини в зрілому віці залежить, насамперед, від іiі активності, діяльнісної динаміки, різноманіття і змісту нових форм професійної діяльності, які вона сама породжує та до яких долучається в ході професіоналізації.

Розглянемо далі, які процеси i результати супроводжують формування професійної компетентності в ході формування професійно-педагогічної компетентності.

Входження у професію на етапі професійного навчання у вищому навчальному закладі припускає:

- усвідомлення студентом суті діяльності професіонала;

- забезпечення науково-технічної бази спеціальних знань 3 предмета засобами технологій навчально-виховного та освітнього процесів;

- професійну адаптацію молодих фахівців у трудовій діяльності;

- формування індивідуального стилю діяльності і професійної майстерності;

- розвиток рис професійної зрілості i компетентності, наприклад, умінь професійного самоаналізу, узагальнення особистого досвіду і досвіду своїх колег, діагностики й експертизи у процесі атестації.

Формування професійної компетентності в майбутніх молодих фахівців змінюється під впливом динаміки професійних і життєвих цінностей, мотивації до навчання, розвитком нового вигляду навчальних закладів, розширення спектру підготовки і технологій освіти. В цілому гуманітаризація професійної освіти виявила й активізувала гнучкість професійних намірів, мобільність інтересів, спостерігається складніша структура мотивів професійної самопідготовки. Сучасна ситуація на ринку праці багато в чому згладжує проблему жорсткості професійного вибору.

Педагогічний процес має широкі i різноманітні можливості формування професійної компетентності магістранта. Наведемо перелік можливостей навчальновиховного й освітнього процесів вищого навчального закладу щодо формування професійно-педагогічної компетентності майбутніх магістрів технологічної освіти:

- наявність основних навчальних курсів;

- включення спеціальних дисциплін для оволодіння теоретичними основами входження в професію з усвідомленням значущості єдності загальної і професійної освіти;

- використання навчальних та виробничих практик для набуття досвіду 
професійної діяльності методом професійних проб; професійно значущих імітаційних та професійних ситуацій у системі лабораторно-практичних занять, педагогічних технологій заняття індивідуальним стилем майбутнього професіонала;

- орієнтація магістра на самопізнання особливостей i можливостей своєї особистості відповідно до вимог професії, зацікавленість в саморозвитку професійно необхідних якостей;

- прагнення до різнобічного розвитку задля можливої перспективної самореалізації в ситуаціях професійної діяльності;

- усвідомлення необхідності актуалізації професійно значущих якостей особистості у процесі навчання за профілем факультету.

Навчально-виховний процес вищого педагогічного навчального закладу під час підготовки фахівця 3 технологічної освіти, здатний, використовуючи потенційні можливості розв'язання завдань i формування професійно-педагогічної компетентності фахівця, забезпечити ефективні педагогічні умови, які спрямовані на «відповідність» навчально-виховного процесу вищого навчального закладу основним характеристикам майбутньої професійної діяльності викладача загальнотехнічних дисциплін та методики навчання технологій.

Отже, формування професійно-педагогічної компетентності $\epsilon$ процесом успішного засвоєння професії, виникнення інтегративної особистісної якості, що дозволяє майбутньому магістрові бути готовим до розв'язання професійних завдань, усвідомлюючи соціальну відповідальність за наслідки їх вирішення та вибудовування сприятливої особистісної перспективи.

\section{Література}

1. Белоновская И. Д. Формирование профессиональной компетентности специалиста: региональный опыт: монография [Текст] / И. Д. Белоновская. - Л. : ИРПО, 2005. - 351 с. 2. Коваль В. О. Професійна індивідуальність майбутнього вчителя української мови / В. О. Коваль // Вісник Черкаського університету: Серія Педагогічні науки. - Черкаси, 2009. - Випуск 157.- С. 86-90.

3. Подласый И. П. Педагогика. Новый курс : учебник для студентов пед. вузов : в 2 кн.] / Иван Павлович Подласый. - М.: ВЛАДОС, 1999. - Кн. 1: Общие основы. Процесс обучения. -576 с. 